\author{
๑I. М. Нікітіна, К. В. Микитин, Н. В. Калашник, Т. В. Бабар, \\ Н. А. Іконописцева, Т. В. Копиця
}

Сулсъкий державний університет

\title{
ПОЛІПИ ЕНДОМЕТРІЯ У ЖІНОК РЕПРОДУКТИВНОГО ВІКУ - СУЧАСНИЙ ЕТІОПАТОГЕНЕТИЧНИЙ ПОГЛЯД НА ПРОБЛЕМУ (ОГЛЯД ЛІТЕРАТУРИ)
}

Гіперпроліферативні захворювання ендометрія у пацієнток дітородного віку $є$ однією 3 основних причин зниження фертильності і ризику розвитку онкологічної патології. Дана публікація присвячена актуальній проблемі, а саме локальній гіперплазії ендометрія, тобто поліпам ендометрія, що потребує на сьогодні ретельного вивчення й удосконалення методів діагностики та лікування даної патології з метою збереження репродуктивної фрункції. Метою наукового пошуку $є$ огляд літератури, присвяченої фракторам ризику, етіології та патогенезу розвитку поліпів ендометрія, ролі хронічного ендометриту в розвитку локальної гіперплазії ендометрія у жінок репродуктивного віку. Провідними ланками етіопатогенезу даної патології $є$ естрогенна стимуляція, що поєднується з недостатністю прогестерону, гормон-незалежна пролісерація, хронічне запалення, патологічний неоваскулогенез, а також порушення імунного статусу в ендометрії. Дослідження маркерів апоптозу, проліферації, рецепторного статусу і оксидативного стресу для визначення інтенсивності проліферативних процесів ендометрія дозволить удосконалити тактику ведення пацієнтів, а розробка на цій основі нових методів прогнозування, корекції та профрілактики поліпів ендометрія сприятиме попередженню рецидиву патології і збереженню репродуктивного здоров'я жінок. Крім того, досліджено роль мікробного та вірусного агентів у розвитку неатипової гіперплазії ендометрія у жінок фертильного віку, особливості експресії рецепторів стероїдних гормонів у патологічно зміненому ендометрії. Оцінено роль ехограсрічних та гістероскопічних методів діагностики поліпів ендометрія. Проведено оцінку впливу поліпів ендометрія на репродуктивну функцію.

Ключові слова: поліп ендометрія; стероїдний рецептор; хронічний ендометрит; естроген; прогестерон; локальна гіперплазія ендометрія.

ПОЛИПЫ ЭНДОМЕТРИЯ У ЖЕНЩИН РЕПРОДУКТИВНОГО ВОЗРАСТА - СОВРЕМЕННЫЙ ЭТИОПАТОГЕНЕТИЧЕСКИЙ ВЗГЛЯД НА ПРОБЛЕМУ (ОБЗОР ЛИТЕРАТУРЫ)

Гиперпролисреративные заболевания эндометрия у пациенток детородного возраста являются одной из основных причин снижения фертильности и риска развития онкологической патологии. Данная публикация посвящена актуальной проблеме, а именно локальной гиперплазии эндометрия, то есть полипам эндометрия, что требует на сегодняшний день тщательного изучения и совершенствования методов диагностики и лечения данной патологии с целью сохранения репродуктивной фрункции. Целью научного поиска является обзор литературы, посвященной фракторам риска, этиологии и патогенезу полипов эндометрия, роли хронического эндометрита в развитии локальной гиперплазии эндометрия у женщин репродуктивного возраста. Ведущими звеньями этиопатогенеза данной патологии являются эстрогенная стимуляция, которая сочетается с недостаточностью прогестерона, гормон-независимая пролисерация, хроническое воспаление, патологический неоангиогенез, а также нарушения иммунного статуса в эндометрии. Исследование маркеров апоптоза, пролиферации, рецепторного статуса и оксидативного стресса для определения интенсивности пролисеративных процессов эндометрия позволит усовершенствовать тактику ведения пациентов, а разработка на этой основе новых методов прогнозирования, коррекции и профилактики полипов эндометрия будет способствовать предотвращению рецидивирования патологии и сохранению репродуктивного здоровья женщин. Кроме того, представлена инсрормация о роли микробного и вирусного агентов в развитии неатипичной гиперплазии эндометрия у женщин феертильного возраста, особенности экспрессии рецепторов стероидных гормонов в патологически измененном эндометрии. Оценена роль эхографических и гистероскопических методов диагностики полипов эндометрия. Проведена оценка влияния полипов эндометрия на репродуктивную фрункцию.

Ключевые слова: полип эндометрия; стероидный рецептор; хронический эндометрит; эстроген; прогестерон; локальная гиперплазия эндометрия.

ENDOMETRIAL POLYPS IN WOMEN OF REPRODUCTIVE AGE - A MODERN ETIOPATHOGENETIC VIEW OF THE PROBLEM (LITERATURE REVIEW)

Hyperproliferative diseases of the endometrium in patients of childbearing age is one of the main causes of decreased fertility and the risk of developing oncological pathology. This publication is devoted to an urgent problem, namely, local endometrial hyperplasia, that is, endometrial polyps, which today requires a thorough study and improvement of methods for diagnosing and treating this pathology in order to preserve reproductive function. The aim of the scientific search is to review the literature on risk factors, etiology and pathogenesis of endometrial polyps, the role of chronic endometritis in the development of local endometrial hyperplasia in women of reproductive age. The leading links in the etiopathogenesis of this pathology are estrogenic stimulation, which is combined with progesterone deficiency, hormone-independent proliferation, chronic inflammation, pathological neoangiogenesis, and impaired immune status in the endometrium. Study of markers of apoptosis, proliferation, receptor status and oxidative stress to determine the intensity of proliferative endometrial processes will improve tactics of patient management, and development on this basis of new forecasting methods, treatment and prevention of endometrial polyps will help prevention of recurrence of pathology and preservation of the reproductive health of women. In addition, information is presented on the role of microbial and viral agents in the development of atypical endometrial hyperplasia in women of fertile age, and on the features of the expression of steroid hormone receptors in the pathologically altered endometrium. The role of echographic and hysteroscopic methods for diagnosing endometrial polyps was evaluated. The assessment of the effect of endometrial polyps on reproductive function was carried out.

Key words: endometrial polyp; steroid receptor; chronic endometritis; estrogen; progesterone; local endometrial hyperplasia. 
Гіперплазія ендометрія (ГЕ) у жінок репродуктивного віку $€$ потенційною причиною зниження фрертильності і ризику розвитку онкозахворювань [1]. Патологія ендометрія складає значну частку у структурі гінекологічної захворюваності та є однією з найчастіших причин госпіталізації [2-4]. Поліпи ендометрія (ПЕ) - це доброякісні локалізовані ураження ендометрія, що містять залози та строму і найчастіше виявляються у жінок репродуктивного віку, складаючи приблизно 17,5 \% [5-7]. Поліпи ендометрія - це доброякісна неатипова локальна гіперплазія ендометрія, що містить залози та строму $[3,8]$. Можуть виникати як поодинокі, так і множинні ураження, а їх розмір може становити від міліметрів до сантиметрів [3, 9]. Іноді поліпи ендометрія містять волокна гладких м'язів, крім залоз та строми, і їх називають аденоміоматозними поліпами [10]. Поширеність поліпів ендометрія коливається від 7,8 до 34,9 \% [11-13]. Деякі дослідження повідомляють, що поширеність поліпів ендометрія вища у безплідних жінок [6-11]. У літературних джерелах $[6,15,16]$ відзначається велике число випадків рецидивування простої гіперплазії ендометрія (0,25-64,7\%) (особливо у жінок із запальними захворюваннями та порушенням функції яєчників), що, зважаючи на онконастороженість, часто стає вирішальним у виборі гістеректомії [17] у жінок репродуктивного віку. Виникнення рецидивів поліпів ендометрія (44,1-64,7 \%) і онконастороженість (до 45,1 \%) $є$ сприяючими фракторами щодо вибору радикальних оперативних втручань, що, відповідно, позбавляє можливості реалізації репродуктивної функції [5, 18-21].

Варто зазначити, що в останні роки змінюється погляд на патогенез гіперпластичних і неопластичних захворювань органів репродуктивної системи. Основним етіологічним чинником розвитку гіперпроліферативних процесів ендометрія $€$ порушення гормонального гомеостазу за рахунок підвищення рівня естрогенів (проліферація ендометрія) на тлі зниження прогестерону та зміни чутливості ендометрія до дії гормональних стимулів [5, 22].

Поліпи ендометрія рідко діагностуються до менархе [19], що свідчить про те, що естрогенна стимуляція ендометрія відіграє вирішальну роль у патогенезі поліпів ендометрія [21, 22]. Вік після 35 років, гіпертонія, ожиріння та діабет - відомі фрактори ризику розвитку поліпів ендометрія $[6,7,19,24]$. Серед цих фракторів вік $є$ чи не найвагомішим фрактором ризику. Існує взаємозв'язок між поліпами ендометрія і такими іншими доброякісними гінекологічними захворюваннями, як поліпи шийки матки та ендометріоз $[12,13,25]$.

Зміна концентрації статевих гормонів не є обов'язковою умовою для виникнення гіперпластичних процесів ендометрія. Відсутність або низька експресія рецепторів стероїдних гормонів у тканині ендометрія більш ніж у половині випадків сприяє повному клінічному одужанню та регресу морфологічних показників [4, 6, 25, 27-29]. Відомо, що жінки, які використовують тамоксифен, мають більш високий ризик розвитку поліпів ендометрія, і поширеність поліпів серед них становить від 30 до $60 \%$ [30]. Такі молекулярні механізми, як надмірна експресія рецепторів естрогену та прогестерону, ароматаза ендометрія, підвищена експресія білка В-клітинної лімфоми та мутації в генах HMGIC та HMGI [Y] [31-33] також беруть участь у розвитку поліпів ендометрія [34].

Деякі класичні морфологічні підходи допускають фракт розвитку ПЕ в місцях осередкової базальної гіперпла- зії ендометрія, де виникають локальні потовщення за рахунок стромально-залозистої гіперплазії [6, 12], що може пояснити схожість двох різних проліферативних патологій. Якщо дифузна гіперплазія розвивається на тлі гормонального дисбалансу, то для локальної гіперплазії пусковим механізмом є наявність травматичного пошкодження ендометрія, наприклад внаслідок наявності стороннього тіла (ВMC) в порожнині матки, чи пошкоджувальна дія хронічного запального процесу (найчастіше трубний кут внаслідок хронічного сальпінгоофориту та цервікальний канал внаслідок цервіциту). Локальне потовщення ендометрія на місці пошкодження чи дії запального агента перетворюється внаслідок посиленої проліферації в локальну гіперплазію, а надалі у поліп ендометрія [1, 6, 19, 35].

Важливу роль у патогенезі розвитку локальної гіперплазії ендометрія відіграє хронічне запалення, що стимулює гормон-незалежну клітинну проліферацію, пригнічення процесів апоптозу, активацію пухлинних фракторів росту, інвазії, пухлинного ангіогенезу та неоваскулогенезу [6, 19, 20, 30]. Трансорормація запального процесу відбувається завдяки хронічній лейкоцитарній інфільтрації. Хронічне запалення провокує розвиток дистрофрічних змін епітелію, інфільтрацію строми лейкоцитами та руйнування міжклітинних контактів, що, у свою чергу, сприяє зменшенню герметичної функції епітелію та порушенню диференціації епітеліальних клітин у процесі метаплазії. Цей процес супроводжується порушенням місцевого гуморального імунітету [6, 7, 9]. Ключову роль в канцерогенезі відіграє оксидативне пошкодження ДНК в клітинах, що характерно для запалення. Дослідження мікробного спектра у жінок 3 ГЕ свідчать, що у 62,3 \% пацієнток репродуктивного віку виявлено патогенну неспецифрічну мікрофрлору в порожнині матки при відсутності лабораторних, ультразвукових та патоморфологічних маркерів запального процесу в ендометрії [5, 21-24, 26-30].

У відомому дослідженні, проведеному В. Є. Радзинським і співавт. (2017), питома вага аутоімунного ендометриту склала 28,4 \% (n=98) від загального числа пацієнток із порушеннями в репродуктивній системі $(n=345)$ [30, 34]. Водночас недостатньо вивчено питання вірусного інфікування та його роль у розвитку поліпів ендометрія. Встановлено, що наявність хронічного ендометриту корелює зі збільшенням шансів розвитку поліпів ендометрія (OR - 1,85 \% Cl - 1,3-2,8). При фріброзі строми на тлі хронічного ендометриту ризик розвитку поліпів ендометрія зростає вдвічі [1, 3, 11, 26, 30].

У пацієнтів із симптоматичними поліпами ендометрія зазвичай спостерігаються аномальні маткові кровотечі, однак більшість поліпів безсимптомні і виявляються випадково [1, 3, 11]. Диференційна діагностика гіперпластичних поліпів ендометрія має вирішальне значення у визначенні тактики лікування пацієнток. На сьогодні ехографрія є провідним методом діагностики захворювань органів малого таза [13, 36-42]. Вимірювання величини передньо-заднього розміру серединного М-ехо має найбільше прогностичне значення при патологічних станах ендометрія. Діагностичні методи, які зазвичай використовують для діагностики поліпів ендометрія, включають двовимірну трансвагінальну сонографрію (2D TVUS), 3-вимірну трансвагінальну сонографрію (3D TVUS), сонографрію із сольовою інфузією (SIS), гістеросальпінго- 
графрію (HSG) та гістероскопію [40-44]. Методом вибору ультразвукової діагностики (УЗД) при гіперпроліферативних станах ендометрія є трансвагінальна ехографія, яка передбачає застосування високочастотних датчиків, що забезпечує кращу візуалізацію акустичного відображення від ендометрія [13, 41-45].

Поліп ендометрія, як правило, має вигляд гіперехогенної маси ендометрія з правильними контурами, що частково або повністю займає порожнину матки [13]. Іноді в поліпі можуть візуалізуватися кістозні простори [46]. Виконання сонографії в проліферативній фразі менструального циклу часто дає найбільш надійні результати (рівень доказовості B) $[41,47]$. За допомогою 2D TVUS можна точно виявити поліпи ендометрія [41-42]. У великому рандомізованому дослідженні 793 жінок було виявлено, що чутливість, специфічність, позитивна прогностична цінність (PPV) та негативна прогностична цінність (NPV) 2D TVUS при виявленні поліпів ендометрія становлять 86, 94, 91 та 90 \% відповідно [42]. Додавання доплерографії з кольоровим картуванням може поліпшити діагностичні можливості 2D TVUS. У деяких дослідженнях доплерографрія 3 кольоровим потоком підвищує чутливість 2D TVUS із 91 до $97 \%$ [42].

Порівняно 3 2D-сонографрією, 3D TVUS із доплерографрією з кольоровим потоком дозволяє вимірювати об'єм ендометрія, а також показники васкуляризації ендометрія та підслизового шару. Деякі дослідження припускають, що використання комбінації ехогенності, товщини та об'єму ендометрія з 3D TVUS може бути кращим, ніж одноразові вимірювання за допомогою 2D TVUS для виявлення поліпів ендометрія [41-43]. На відміну від них, інші показали, що неконтрастний 3D TVUS не обов'язково збільшує виявлення поліпів ендометрія порівняно з 2D TVUS. Додавання внутрішньоматкового контрасту (фрізіологічний розчин або гель) підвищує точність діагностики 2D TVUS та 3D TVUS. Додаткові переваги SIS включають оцінку інших аномалій порожнини матки, таких як лейоміоми або спайки, та оцінку мюллерових аномалій, якщо це необхідно [39, 42, 47, 48]. Недоліки інфрузійної сонограффії пов'язані з дискомфортом пацієнта, спричиненим введенням або витоком рідини [49], а також теоретичним ризиком інфрікування [50].

Гістеросальпінгографрія (HSG) дозволяє проводити візуалізацію цервікального каналу, порожнини матки та маткових труб з ін'єкцією контрастних речовин за допомогою фрлюороскопічної візуалізації. Як правило, доступ до цервікального каналу або порожнини ендометрія здійснюється за допомогою асептичної техніки. Невеликий об'єм (10-30 мл) контрастної речовини вводять під час переривчастої фрлюороскопії для візуалізації структур, які слід зобразити. Іноді при підозрі на патологію ендометрія можна отримати зображення після дренажу [43]. HSG має високу чутливість (98 \%), але низьку специфічність $(34,6$ \%) та PPV $(28,6$ \%) порівняно з гістероскопією для поліпів ендометрія [43, 46, 48, 51-52].

Гістероскопія з керованою біопсією вважається золотим стандартом діагностики поліпів ендометрія. Гістероскопія також полегшує оцінку розміру, кількості та судинних характеристик поліпів ендометрія [51, 52]. До звичайного використання гістероскопії для діагностики поліпів ендометрія використовували сліпе розширення та кюретаж [50]. Однак ця методика спричиняла фррагмента- цію поліпів, ускладнюючи гістологічну діагностику. Низька чутливість від 8 до 46 \% та NPV від 7 до 58 \% відбору зразків сліпого ендометрія порівняно з гістероскопією 3 керованою біопсією [47] свідчить про те, що попередню методику не слід застосовувати для діагностики поліпів ендометрія.

Вітчизняні вчені (А. В. Бойчук і співавт., 2019) стверджують, що одним із ключових сракторів успішного настання вагітності є стан ендометрія в період вікна імплантації, коли проходить активація процесів апоптозу в ендометрії і їх наявність виступає в ролі біологічного маркера адекватно підготовленого до імплантації ендометрія [6, 11]. Взаємодія між ембріоном та рецептивним ендометрієм зумовлює важливу складову ранньої імплантації, що згодом впливає на плацентацію та продовження здорової вагітності $[48,49,52]$. Вважається, що патологічні утвори, такі як поліпи, лейоміоми або синехії, можуть порушити процес імплантації $[52,53]$. Хоча ізольоване безпліддя, пов'язане з маткою, можна виявити у 2-3 \% безплідних жінок, внутрішньоутробні ураження можуть бути виявлені приблизно у 40-50 \% субфертильних чи безплідних жінок [53]. Попередні дослідження показали, що резекція поліпів ендометрія може сприяти збільшенню природного зачаття, а також збільшенню частоти вагітності при застосуванні допоміжних репродуктивних технологій [45, $47,53]$. Хірургічну резекцію поліпів ендометрія рекомендують пацієнтам із безпліддям до початку лікування 3 метою збільшення частоти випадків природного зачаття або покращення результатів застосування допоміжних репродуктивних технологій. Гістероскопічна поліпектомія залишається золотим стандартом хірургічного лікування.

Природний перебіг поліпів ендометрія недостатньо вивчений. Вважається, що невеликі поліпи ендометрія (<10 мм) спонтанно регресують приблизно у 25 \% випадків. Роль медикаментозного лікування у випадку поліпів ендометрія обмежена $[7,12,13]$. Внутрішньоматкові пристрої, що містять левоноргестрел, використовувались для зменшення частоти рецидивування поліпів ендометрія [6]. Застосовують також агоністи гонадотропних рилізинггормонів як допоміжне лікування перед гістероскопічною резекцією. Однак немає достатньої кількості даних, що підтверджують корисність цього метода як засобу першого ряду для лікування поліпів ендометрія [43].

Хоча поліпи ендометрія можуть спонтанно регресувати і, можливо, піддаються гормональній терапії, остаточні варіанти лікування в основному хірургічні. Сліпа дилатація та кюретаж можуть усунути поліпи ендометрія приблизно у 8 \% пацієнтів $[43,44]$. Додавання поліпних щипців збільшує повне вилучення поліпів приблизно у $41 \%$ пацієнтів [43]. Загалом, сліпе розширення та кюретаж можуть пропустити патологію ендометрія приблизно в 50 \% випадків, і тому, коли доступна гістероскопія, їх варто уникати $[43,44]$.

Гістероскопічна поліпектомія залишається золотим стандартом як для діагностики, так і для лікування поліпів ендометрія. Загальним методом гістероскопічної поліпектомії, як правило, є той, якому клініцист навчений та з якими найкраще обізнаний [43]. Ризик внутрішньоутробних спайок після гістероскопічної поліпектомії низький, оскільки міометрій, як правило, не ушкоджений [44].

Згідно з літературними даними, передбачувані механізми, за допомогою яких поліпи ендометрія негативно 
впливають на фертильність, можуть бути пов'язані з механічними перешкодами для транспортування сперми або як пошкодження ендометрія, що заважають імплантації ембріонів [45]. Залози та строма у поліпів ендометрія не реагують на стимуляцію прогестероном, що призводить до порушення імплантації плідного яйця на місці поліпа [45, 46]. Поліпи ендометрія можуть також індукувати місцеві запальні зміни, які перешкоджають нормальній імплантації та розвитку ембріона [45-47]. Ці запальні зміни опосередковані збільшенням кількості опасистих клітин у порожнині ендометрія, а також підвищенням рівня матриксної металопротеїнази-2 та металопротеїнази-9. Поліпи ендометрія можуть виробляти глікоделін, глікопротеїн, який пригнічує природну активність клітин-кілерів, роблячи ендометрій менш сприйнятливим до імплантації $[6,52]$.

Наукові дослідження демонструють, що резекція поліпів ендометрія може покращити природні показники зачаття $[33,43,52]$. У суборертильних жінок гістероскопічна поліпектомія може покращити фертильність від 43 до 80 \% [50]. Останні наукові дослідження також продемонстрували, що показники вагітності покращуються у пацієнтів, які перенесли поліпектомію до внутрішньоутробного запліднення (IVF) [53]. В одному проспективному рандомізованому дослідженні, у якому брали участь 215 жінок, у пацієнток, які перенесли поліпектомію до IVF, рівень вагітності збільшився (51,4 \%) порівняно 3 пацієнтами, які цього не зробили (25,4%) [52]. Також було доведено, що гістероскопічна резекція поліпів ендометрія (до 16 мм) до IVF збільшує шанси на клінічну вагітність (OR - 4,4, $95 \%$ Cl 2,5-8,0) принаймні протягом 2 років [53]. Резекція вперше діагностованих поліпів ендометрія під час гістерорезектоскопії може зменшити показники втрати вагітності та збільшити рівень народжуваності.

ВИсновкИ. 1. Складність і неоднозначність патогенезу поліпів ендометрія, неоднозначність тактичних підходів створюють певні труднощі у виборі патогенетично обґрунтованого лікування.

2. Виявлення ознак запального процесу в гіперплазованому ендометрії обґрунтовує необхідність проведення етіотропної терапії до призначення гормонального чи хірургічного лікування.

3. Хронічний ендометрит є фоном для розвитку поліпів ендометрія, що мають негативний вплив на фертильність. Гістероскопічна поліпектомія залишається золотим стандартом хірургічного лікування поліпів ендометрія та рекомендується для пацієнток із безпліддям, що може збільшити шанси на природне зачаття та результативність застосування допоміжних репродуктивних технологій.

\section{СПИСОК ЛІТЕРАТУРИ}

1. Morphological features of uterine polyps in females of reproductive age / N. Y. Gorban, T. D. Zadorozhna, I. B. Vovk, I. V. Zhulkevych // Вісник наукових досліджень. - 2019. № 2. - C. 47-52.

2. Биштави A. X. Современные представления о гиперплазии эндометрия и эндометриальной интраэпителиальной неоплазии / А. Х. Биштави, И. Б. Манухин, Ю. Ю. Табакман // Проблемы репродукции. - 2010. - № 6. - С. 52-58.

3. Морфоорункциональное состояние эндометрия у женщин с бактериально-вирусным эндометритом / Л.И. Мальцева, Р.И. Шарипова,Д. Э.Цыплаков, М.Е. Железова// Практическая медицина. - 2017. - № 7 (108). - С. 87-91.

4. Микрофрора влагалища и цервикального канала у женщин с полипами шейки матки / О. В. Макаров, Т. Н. Савченко, В. А. Алёшкин [и др.] // Вестник Российского государственного медицинского университета. - 2011. № 4. - C. 43-47.

5. Павловская М. А. Гиперплазия эндометрия у женщин фертильного возраста. Клиника, диагностика, патогенез и возможности терапии / М. А. Павловская // Журнал Гродненского медицинского университета. - 2015. - № 2. - С. 123-127.

6. Бойчук А. В. Гіперплазія ендометрія - сучасний системно-патогенетичний погляд на проблему (огляд літератури) / А. В. Бойчук, В. С. Шадріна, Т. В. Верещагіна // Актуальні питання педіатрії, акушерства та гінекології. - 2019. № 1. - С. 67-72.

7. Вовк И. Б. Современные представления о гиперплазии эндометрия / И. Б. Вовк, О. Ю. Борисюк, Н. Е. Горбань // Медична газета «Здоров'я України». Гінекологія. Акушерство. Репродуктологія. - 2016. - № 2 (22). - С. 70-73.

8. Peculiarities of Uterine Cavity Biocenosis in Patients with Different Types of Endometrial Hyperproliferative Pathology I N. Y. Horban, I. B. Vovk, T. O. Lysiana [et al.] // J. Med. Life. 2019. - Vol. 12 (3). - P. 266-270.

9. Бенюк В. О. Сучасні підходи до діагностики гіперпластичних процесів ендометрія у жінок репродуктивного віку / В. О. Бенюк, В. В. Курочка, В. М. Гончаренко // Проблемы, достижения и перспективы развития медико-биологических наук и практического здравоохранения. - 2009. - Т. 145, № 3. - С. 3004-3005.

10. Патогенетические аспекты гиперпластических процессов в эндометрии у женщин с метаболическим синдромом / С. О. Дубовина, Н. Н. Скачков, Ю. Д. Берлим [и др.] // Российский вестник акушера-гинеколога. - 2008. - № 3. C. 41-44.

11. Boychuk A. V. Estimation of relative risk of development and informativeness of diagnostic metods of hiperproliferative processes of endometrium / A. V. Boychuk, T. V. Vereshchahina, I. M. Nikitina // Wiadomości Lekarskie (Warsav. Poland: 1960). - 2020. - Vol. LXXIII, Issue 9. - P. 1600-1609.

12. Immunoglobulin indicators to viruses citomegal and genital herpes in the blood serum of women with non-atipycal endometrial hiperproliferative pathology / N. E. Gorban, I. B. Vovk, I. M. Nikitina [et al.] // Wiadomości Lekarskie. (Warsav. Poland: 1960). - 2020. - Vol. LXXIII, Issue 8. - P. 1600-1605.

13. Горбань Н. $€$. Оцінка ехографрічних показників у жінок 3 гіперпроліфреративною патологією ендометрія / Н. Є. Горбань, В. К. Кондратюк, І. І. Ракша // Актуальні питання педіатрії, акушерства та гінекології. - 2019. - № 2. - С. 32-38.

14. Absolute risk of endometrial carcinoma during 20year follow-up among women with endometrial hyperplasia / J. V. Lacey, M. E. Sherman, B. B. Rush [et al.] // J. Clin. Oncol. - 2010. - Vol. 28 (5). - P. 788-792.

15. Жулкевич І. В. Персоналізація в онкології: індивідуальний підхід до профілактики тромбоемболічних ускладнень при пангістеректомії / І. В. Жулкевич, Б. Д. Кривокульський // Вісник соціальної гігієни та організації охорони здоров'я України. - 2018. - № 4 (78). - С. 11-18.

16. Antonsen S. L. Patients with atypical hyperplasia of the endometrium should be treated in oncological centers / S. L. Antonsen, L. Ulrich, C. Hogdall // Gynecol. Oncol. - 2012. - Vol. 125 (1). - P. 124-128.

17. Comparison of WHO and endometrial intraepithelial neoplasia classifications in predicting the presence of coex- 
istent malignancy in endometrial hyperplasia / M. C. Salman, A. Usubutun, K. Boynukalin, K. Yuce // J. Gynecol. Oncol. 2010. - Vol. 21 (2). - P. 97-101.

18. Conservative treatment of early endometrial cancer: preliminary results of a pilot study / G. Laurelli, G. Di Vagno, C. Scaffa [et al.] // Gynecol. Oncol. - 2011. - Vol. 120 (1). - P. 43-46.

19. Вивчення впливу віку та індексу коморбідності на ризик тромботичних ускладнень у хворих на рак ендометрія на доопераційному етапі / Б. Д. Кривокульський, І. В. Жулкевич, Д. Б. Кривокульський, Л. В. Шкробот // Вісник наукових досліджень. - 2018. - № 2 (91). - С. 151-153.

20. Экспрессия генов, регулирующих апоптоз, при разных типах гиперплазии эндометрия и эндометриоидной карциноме / Г. Е. Чернуха, М. Р. Думановская, О. В. Бурменская [и др.] // Акушерство и гинекология. - 2013. - № 1. - С. 63-69.

21. Potential contribution of the uterine microbiome in the development of endometrial cancer / M. R. Walther-António, J. Chen, F. Multinu [et al.] // Genome Med. - 2016. - Vol. 8 (1). - P. 122.

22. The diagnosis of chronic endometritis in infertile asymptomatic women: a comparative study of histology, microbial cultures, hysteroscopy, and molecular microbiology / I. Moreno, E. Cicinelli, I. Garcia-Grau [et al.] // Am. J. Obstet. Gynecol. 2018. - Vol. 218 (6). - P. 602.

23. Состояние микроценоза полости матки у пациенток с простыми гиперплазиями эндометрия / И. И. Куценко, Э. Р. Аракелян, И. О. Боровиков, Ю. С. Сафронова// Современные проблемы науки и образования. - 2014. - № 2. - С. 283.

24. Подольський Вл. В. Стан мікробіоценозу урогенітальних органів у жінок з порушенням репродуктивного здоров'я та змінами вегетативного гомеостазу / Вл. В. Подольський, Т. О. Лісяна, І. Г. Пономарьова // Здоровье женщины. - 2015. - № 2. - C. 142-150.

25. Пономаренко К. Ю. Рецептивность эндометрия у женщин с нарушениями в репродуктивной системе / К. Ю. Пономаренко // Журнал акушерства и женских болезней. - 2017. - Т. 66, № 4. - С. 90-97.

26. Особливості аеробної та анаеробної мікрофрлори у жінок 3 гіперпроліферативними захворюваннями матки і ендометрія / І. Б. Вовк, А. Г. Корнацька, Т. О. Лисяна [та ін.] // Здоровье женщины. - 2016. - № 2. - С. 102-106.

27. Franasiak J. M. Reproductive tract microbiome in assisted reproductive technologies / J. M. Franasiak, R.T. Jr. Scott // Fertil. Steril. -2015. - Vol. 104 (6). - P. 1364-1371.

28. Доброхотова Ю. Э. Микробиота репродуктивного тракта и гиперпластические процессы эндометрия (обзор литературы) / Ю. Э. Доброхотова, К. К. Якубова // РМЖ. Медицинское обозрение. - 2018. - № 10. - С. 14-16.

29. Incidence of endometrial hyperplasia / S. D. Reed, K. M. Newton, W. L. Clinton [et al.] // Am. J. Obstet. Gynecol. 2009. - Vol. 200. - P. 678. e1-6.

30. Патогенетические особенности макротипов хронического эндометрита / В. Е. Радзинский, Ю. А. Петров, Е. А. Калинина [и др.] // Казанский медицинский журнал. 2017. - № 1 (98). - C. 27-34.

31. Heterogeneity in endometrial expression of aromatase in polyp-bearing uteri / L. Pal, A. L. Niklaus, M. Kim [et al.] // Hum. Reprod. - 2008. - Vol. 23 (1). - P. 80-84.

32. Aromatase and cyclooxygenase-2 expression in endometrial polyps during the menstrual cycle / $\mathrm{H}$. Maia Jr., K. Pimentel, T. M. Correia Silva [et al.] // Gynecol. Endocrinol. - 2006. - Vol. 22 (4). - P. 219-224.

33. Горбань Н. Е. Полип и гиперплазия эндометрия этиопатогенетические аспекты рационального подхода к проблеме / Н. Е. Горбань // Вісник наукових досліджень. 2017. - № 4. - C. 67-72.
34. Радзинский В. Е. Хронический эндометрит: современные аспекты / В. Е. Радзинский, Ю. А. Петров, М. Л. Полина // Кубанский научный медицинский вестник. 2017. - № 24 (5). - С. 69-74.

35. Diagnostic accuracy of saline infusion sonography in the evaluation of uterine cavity abnormalities prior to assisted reproductive techniques: a systematic review and meta-analyses / S. Seshadri, T. El-Toukhy, A. Douiri, [et al.] // Hum. Reprod. Update. - 2015. - Vol. 21 (2). P. 262-274.

36. Value of 3-dimensional and power Doppler sonography for diagnosis of endometrial polyps / L. Fang, Y. Su, Y. Guo, Y. Sun // J. Ultrasound Med. - 2013. - Vol. 32 (2). - P. 247-255.

37. Application of 3D ultrasonography in detection of uterine abnormalities / F. Ahmadi, F. Zafarani, H. Haghighi [et al.] // Int. J. Fertil. Steril. - 2011. - Vol. 4 (4). - P. 144-147.

38. American Association of Gynecologic Laparoscopists. AAGL practice report: practice guidelines for the diagnosis and management of endometrial polyps // J. Minim. Invasive Gynecol. - 2012. - Vol. 19 (1). - P. 3-10.

39. Evaluation of abnormal uterine bleeding by transvaginal 3-D hysterosonography and diagnostic hysteroscopy / N. Makris, N. Skartados, K. Kalmantis [et al.] // Eur. J. Gynaecol. Oncol. 2007. - Vol. 28 (1). - P. 39-42.

40. Diagnostic hysteroscopy and saline infusion sonography: prediction of intrauterine polyps and myomas / F. W. Jansen, C. D. de Kroon, H. van Dongen [et al.] // J. Minim. Invasive Gynecol. - 2006. - Vol. 13 (4). - P. 320-324.

41. The diagnostic accuracy of two- vs three-dimensional sonohysterography for evaluation of the uterine cavity in the reproductive age / W. El-Sherbiny, A. El-Mazny, N. Abou-Salem, W. S. Mostafa // J. Minim. Invasive Gynecol. - 2015. - Vol. 22 (1). - P. 127-131.

42. Abou-Salem N. Value of 3-dimensional sonohysterography for detection of intrauterine lesions in women with abnormal uterine bleeding / N. Abou-Salem, A. Elmazny, W. El-Sherbiny // J. Minim. Invasive Gynecol. - 2010. - Vol. 17 (2). - P. 200-204.

43. Preutthipan S. A prospective comparative study between hysterosalpingography and hysteroscopy in the detection of intrauterine pathology in patients with infertility / S. Preutthipan, V. Linasmita // J. Obstet. Gynaecol. Res. - 2003. - Vol. 29 (1). P. 33-37.

44. Can we rely on blind endometrial biopsy for detection of focal intrauterine pathology? / R. Svirsky, N. Smorgick, U. Rozowski [et al.] / Am. J. Obstet. Gynecol. -2008. - Vol. 199 (2). - P. 115.e1-115.

45. Impact of newly diagnosed endometrial polyps during controlled ovarian hyperstimulation on in vitro fertilization outcomes / R. T. Elias, N. Pereira, F. S. Karipcin [et al.] // J. Minim. Invasive Gynecol. - 2015. - Vol. 22 (4). - P. 590-594.

46. Hysteroscopy for treating subfertility associated with suspected major uterine cavity abnormalities / J. Bosteels, J. Kasius, S. Weyers [et al.] // Cochrane Database Syst. Rev. 2015. - No. 2. - Article ID CD009461.

47. Carneiro M. M. What is the role of hysteroscopic surgery in the management of female infertility? A review of the literature / M. M. Carneiro // Surg. Res. Pract. - 2014. - Vol. 2014. 6 p. - Article ID 105412.

48. Deans R. Review of intrauterine adhesions / R. Deans, J. Abbott // J. Minim. Invasive Gynecol. - 2010. - Vol. 17 (5). - P. 555-569.

49. Taylor E. The uterus and fertility / E. Taylor, V. Gomel // Fertil. Steril. - 2008. - Vol. 89 (1). - P. 1-16.

50. Management of endometrial polyps in subfertile women: a systematic review / K. Afifi, S. Anand, S. Nallapeta, T. A. Gelbaya // Eur. J. Obstet. Gynecol. Reprod. Biol. - 2010. - Vol. 151 (2). - P. 117-121. 
51. Hysteroscopy for treating subfertility associated with suspected major uterine cavity abnormalities / J. Bosteels, J. Kasius, S. Weyers [et al.] // Cochrane Database Syst. Rev. 2015. - No. 2. - Article ID CD009461.

52. Endometrial polyps and their implication in the pregnancy rates of patients undergoing intrauterine insemination: a prospective, randomized study / T. Pérez-Medina, J. Bajo-
Arenas, F. Salazar [et al.] // Hum. Reprod. - 2005. - Vol. 20 (6). P. 1632-1635.

53. Treating suspected uterine cavity abnormalities by hysteroscopy to improve reproductive outcome in women with unexplained infertility or prior to IUI, IVF, or ICSI / J. Bosteels, J. Kasius, S. Weyers [et al.] // Gynecol. Surg. - 2013. - Vol. 10 (3). - P. 165-167.

\section{REFERENCES}

1. Gorban, N.Y., Zadorozhna, T.D., Vovk, I.B., \& Zhulkevych, I.V. (2019). Morphological features of uterine polyps in females of reproductive age. Visnyk naukovykh doslidzhen - Bull. Sci. Res., 2, 47-52.

2. Bishtavi, A.Kh., Manukhin, I.B., \& Tabakman, Yu.Yu. (2010). Sovremennyye predstavleniya o giperplazii endometriya i endometrialnoy intraepitelialnoy neoplazii [Modern concepts of endometrial hyperplasia and endometrial intraepithelial neoplasia]. Problemy reproduktsii - Problems of Reproduction, 6, $52-58$ [in Russian].

3. Maltseva, L.I., Sharipova, R.I., Tsyplakov, D.E., \& Zhelezova, M.Ye. (2017). Morfofunktsionalnoye sostoyaniye endometriya $\mathrm{u}$ zhenshchin $\mathrm{s}$ bakterialno-virusnym endometritom [Morphofunctional state of the endometrium in women with bacterial-vira endometritis]. Prakticheskaya meditsina - Practical Medicine, 7 (108), 87-91 [in Russian].

4. Makarov, O.V., Savchenko, T.N., Aloshkin, V.A., Afanasyev, S.S., Voropayeva, Ye.A., Melnikov, A.V., \& Batiyan, T.S. (2011). Mikroflora vlagalishcha i tservikalnogo kanala u zhenshchin s polipami sheyki matki [Microflora of the vagina and cervical canal in women with cervical polyps]. Vestnik Rossiyskogo gosudarstvennogo meditsinskogo universiteta - Bulletin of the Russian State Medical University, 4, 43-47 [in Russian].

5. Pavlovskaya, M.A. (2015). Giperplaziya endometriya u zhenshchin fertilnogo vozrasta. Klinika, diagnostika, patogenez i vozmozhnosti terapii [Endometrial hyperplasia in women of fertile age. Clinic, diagnostics, pathogenesis and therapy possibilities]. Zhurnal Grodnenskogo meditsinskogo universiteta - Journal of Grodno Medical University, 2, 123-127 [in Russian].

6. Boichuk, A.V., Shadrina, V.S., \& Vereshchahina, T.V. (2019). Hiperplaziia endometriia - suchasnyi systemnopatohenetychnyi pohliad na problemu (ohliad literatury) [Hyperplasia of endometrium - a modern system-pathogenetic view on the problem (literature review)]. Aktualni pytannia pediatrii, akusherstva ta hinekolohii - Actual Problems of Pediatrics, Obstetrics and Gynecology, 1, 67-72. Retrieved from: https://doi.org/10.11603/24116-4944.2019.1.9906 [in Ukrainian].

7. Vovk, Y.B., Borysyuk, O.Yu., \& Horban, N.Ye. (2016). Sovremennye predstavleniya o giperplazii endometriya [Modern ideas about endometrial hyperplasia]. Medychna hazeta "Zdorovia Ukrainy". Hinekolohiia. Akusherstvo. Reproduktolohiia - Medical newspaper "Health of Ukraine". Gynecology. Obstetrics. Reproductology, 2 (22), 70-73 [in Russian].

8. Horban, N.Y., Vovk, I.B., Lysiana, T.O., Ponomariova, I.H., \& Zhulkevych, I.V. (2019). Peculiarities of uterine cavity biocenosis in patients with different types of endometrial hyperproliferative pathology. J. Med. Life., 12 (3), 266-270.

9. Beniuk, V.O., Kurochka, V.V., \& Honcharenko, V.M. (2009). Suchasni pidkhody do diahnostyky hiperplastychnykh protsesiv endometriia u zhinok reproduktyvnoho viku [Modern approaches to the diagnosis of hyperplastic processes of the endometrium in women of reproductive age]. Problemy, dostizheniya i perspektivy razvitiya mediko-biologicheskikh nauk i prakticheskogo zdravookhraneniya - Problems, Achievements and Prospects for the Development of Biomedical Sciences and Practical Health Care, 145, 3, 3004-3005 [in Russian].
10. Dubrovina, S.O., Skachkov, N.N., Berlim, Yu.D., Zinkin, V.I., Zinkina, Ye.V., \& Maklyuk, A.M. (2008). Patogeneticheskiye aspekty giperplasticheskikh protsessov $v$ endometrii u zhenshchin s metabolicheskim sindromom [Pathogenetic aspects of hyperplastic processes in the endometrium in women with metabolic syndrome]. Rossiyskiy vestnik akushera-ginekologa - Russian Bulletin of Obstetrician-Gynecologist, 3, 41-44 [in Russian].

11. Boychuk, A.V., Vereshchahina, T.V., \& Nikitina, I.M. (2020). Estimation of relative risk of development and informativeness of diagnostic methods of hiperproliferative processes of endometrium. Wiadomości Lekarskie (Warsav. Poland: 1960), LXXIV (9), 1600-1609.

12. Gorban, N.E., Vovk, I.B., Nikitina, I.M., Kondratiuk, V.K., \& Yemets, N.O. (2020). Immunoglobulin indicators to viruses citomegal and genital herpes in the blood serum of women with non-atipycal endometrial hiperproliferative pathology. Wiadomości Lekarskie (Warsav. Poland: 1960), LXXIII (8), 1600-1605.

13. Gorban, N.Y., Kondratyuk, V.K., \& Raksha, I.I. (2019). Otsinka ekhohrafichnykh pokaznykiv u zhinok z hiperproliferatyvnoiu patolohiieiu endometriia [Evaluation of ultrasound parameters in women with endometrial hyperproliferative pathology]. Aktualni pytannia pediatrii, akusherstva ta hinekolohii - Actual Problems of Pediatrics, Obstetrics and Gynecology, 2, 32-38. Retrieved from: https:// doi.org/10.11603/24116-4944.2019.2.10924 (2), 32-38 [in Ukrainian].

14. Lacey, J.V., Sherman, M.E., Rush, B.B., Ronnett, B.M., loffe, O.B., Duggan, M.A., ..., \& Langholz, B. (2010). Absolute risk of endometrial carcinoma during 20-year follow-up among women with endometrial hyperplasia. J. Clin. Oncol., 28 (5), 788-792.

15. Zhulkevych, I.V., \& Kryvokulskyi, B.D. (2018). Personalizatsiia v onkolohii: indyvidualnyi pidkhid do profilaktyky tromboembolichnykh uskladnen pry panhisterektomii [Personalization in oncology: individual approach to the prevention of thromboembolic complications during hysterectomy]. Visnyk sotsialnoi hihiieny ta orhanizatsii okhorony zdorovia Ukrainy - Bulletin of Social Hygiene and Health Protection Organization of Ukraine, 4, 11-18 [in Ukrainian].

16. Antonsen, S.L., Ulrich, L., \& Hogdall, C. (2012). Patients with atypical hyperplasia of the endometrium should be treated in oncological centers. Gynecol. Oncol., 125 (1), 124-128.

17. Salman, M.C., Usubutun, A., Boynukalin, K., Yuce, K. (2010). Comparison of $\mathrm{WHO}$ and endometrial intraepithelial neoplasia classifications in predicting the presence of coexistent malignancy in endometrial hyperplasia. J. Gynecol. Oncol., 21 (2), 97-101.

18. Laurelli, G., Di Vagno, G., Scaffa, C., Losito, S., Del Giudice, M., \& Greggi, S. (2011). Conservative treatment of early endometrial cancer: preliminary results of a pilot study. Gynecol Oncol., 120 (1), 43-46.

19. Kryvokulskyi, B.D., Zhulkevych, I.V., Kryvokulskyi, D.B., \& Shkrobot, L.V. (2018). Vyvchennia vplyvu viku ta indeksu ko- 
morbidnosti na ryzyk trombotychnykh uskladnen u khvorykh na rak endometriia na dooperatsiinomu etapi [Studying the influence of age and comorbidity index on the thrombotic complications risk in patients with endometrial cancer at preoperative stage] Visnyk naukovykh doslidzhen - Bull. Sci. Res., 2 (91), 151-153 [in Ukrainian].

20. Chernukha, G.E., Dumanovskaya, M.R., Burmenskaya, O.V., Shubina, E.S., Kogan, E.S., \& Trofimov, D.Yu. (2013). Ekspresiya genov, reguliruyushchikh apoptoz, pri raznykh tipakh giperplazii endometriya i endometroidnoy kartsinome [Expression of genes regulating apoptosis in different types of endometrial hyperplasia and endometrioid carcinoma]. Akusherstvo i ginekologiya - Obstetrics and Gynecology, 1, 63-69 [in Russian].

21. Walther-António, M.R., Chen, J., Multinu, F., Hokenstad, A., Distad, T.J., Cheek, E.H., ..., \& Chia, N. (2016). Potentia contribution of the uterine microbiome in the development of endometrial cancer. Genome Med., 8 (1), 122.

22. Moreno, I., Cicinelli, E., Garcia-Grau, I., Gonzalez-Monfort, M., Bau, D., Vilella, F., ..., \& Simon, C. (2018). The diagnosis of chronic endometritis in infertile asymptomatic women: a comparative study of histology, microbial cultures, hysteroscopy, and molecular microbiology. Am. J. Obstet. Gynecol., 218 (6), 602.

23. Kutsenko, I.I., Arakelyan, E.R., Borovikov, I.O., \& Safronova, Yu.S. (2014). Sostoyaniye mikrotsenoza polosti matki u patsiyentok s prostymi giperplaziyami endometriya [The state of microcenosis of the uterine cavity in patients with simple endometrial hyperplasia]. Sovremennyye problemy nauki i obrazovaniya - Modern Problems of Science and Education, 2, 283.

24. Podolskyi, VI.V., Lisyana, T.O., \& Ponomarova, I.H. (2015). Stan mikrobiotsenozu urohenitalnykh orhaniv u zhinok z porushenniam reproduktyvnoho zdorovia ta zminamy vehetatyvnoho homeostazu [The state of the microbiocenosis of urogenital organs in women with reproductive health disorders and changes in autonomic homeostasis]. Zdorovye zhenshchiny - Women's Health, 2, 142-150 [in Ukrainian].

25. Ponomarenko, K. Yu. (2017). Retseptivnost endometriya $\mathrm{u}$ zhenshchin s narusheniyami $\mathrm{v}$ reproduktivnoy sisteme [Endometrial receptivity in women with reproductive disorders]. Zhurnal akusherstva i zhenskikh bolezney - Journal of Obstetrics and Women's Diseases, 66, 4, 90-97 [in Russian].

26. Vovk, I.B., Kornatska, A.H., Lysyana, T.O., Horban, N.Ye., \& Ponomarov, I.H. (2016). Osoblyvosti aerobnoi ta anaerobnoi mikroflory u zhinok z hiperproliferatyvnymy zakhvoriuvanniamy matky i endometriia [Peculiarities of aerobic and anaerobic microflora in women with hyperproliferative diseases of the uterus and endometrium]. Zdorove zhenshchyny - Women's Health, 2, 102-106 [in Ukrainian].

27. Franasiak, J.M., \& Scott, R.T.Jr. (2015). Reproductive tract microbiome in assisted reproductive technologies. Fertil. Steril., 104 (6), 1364-1371.

28. Dobrokhotova, Yu.E., \& Yakubova, K.K. (2018). Mikrobiota reproduktivnogo trakta i giperplasticheskiye protsessy endometriya (obzor literatury). RMZh. Meditsinskoye obozreniye - RMJ. Medical Review, 10, 14-16 [in Russian].

29. Reed, S.D., Newton, K.M., Clinton, W.L., Epplein, M., Garcia, R., Allison, K., ..., \& Weiss, N.S. (2009). Incidence of endometrial hyperplasia. Am. J. Obstet. Gynecol., 200, 678, e1-6.

30. Radzinskiy, V.Ye., Petrov, Yu.A., Kalinina, Ye.A., Shirokova, D.V., \& Polina, M.L. (2017). Patogeneticheskiye osobennosti makrotipov khronicheskogo endometrita [Pathogenetic features of the macrotypes of chronic endometritis]. Kazanskiy meditsinskiy zhurnal - Kazan Medical Journal, 98 (1), 27-34 [in Russian].

31. Pal, L., Niklaus, A.L., Kim, M., Pollack, S., \& Santoro, N. (2008). Heterogeneity in endometrial expression of aromatase in polyp-bearing uteri. Hum. Reprod., 23 (1), 80-84.

32. Maia, H.Jr., Pimentel, K., Silva, T.M., Freitas, L.A., Zausner, B., Athayde, C., \& Coutinho, E.M. (2006). Aromatase and cyclooxygenase-2 expression in endometrial polyps during the menstrual cycle. Gynecol. Endocrinol., 22 (4), 219-224.

33. Gorban, N.Ye. (2018). Polip i giperplaziya endometriya - etiopatogeneticheskiye aspekty ratsionalnogo podkhoda $\mathrm{k}$ probleme [Polyp and endometrial hyperplasia - etiopathogenetic aspects of a rational approach to the problem]. Visnyk naukovykh doslidzhen - Bull. Sci. Res., 4. Retrieved from https://doi. org/10.11603/2415-8798.2017.4.8246 [in Ukrainian].

34. Radzinskiy, V.Ye., Petrov, Yu.A., Polina, M.L. (2017). Khronicheskiy endometrit: sovremennyye aspekty [Chronic endometritis: modern aspects]. Kubanskiy nauchnyy meditsinskiy vestnik - Kuban Sci. Med. Bull., 24 (5), 69-74 [in Russian].

35. Seshadri, S., El-Toukhy, T., Douiri, A., Jayaprakasan, K., \& Khalaf, Y. (2015). Diagnostic accuracy of saline infusion sonography in the evaluation of uterine cavity abnormalities prior to assisted reproductive techniques: a systematic review and meta-analyses. Hum. Reprod. Update, 21 (2), 262-274.

36. Fang, L., Su, Y., Guo, Y., \& Sun, Y. (2013). Value of 3-dimensional and power Doppler sonography for diagnosis of endometrial polyps. J. Ultrasound Med., 32 (2), 247-255.

37. Ahmadi, F., Zafarani, F., Haghighi, H., Niknejadi, M., \& Dizaj, A.V.T. (2011). Application of 3D ultrasonography in detection of uterine abnormalities. Int. J. Fertil. Steril., 4 (4), 144-147.

38. American Association of Gynecologic Laparoscopists. (2012). AAGL practice report: practice guidelines for the diagnosis and management of endometrial polyps. J. Minim. Invasive Gynecol., 19, (1), 3-10.

39. Makris, N., Skartados, N., Kalmantis, K., Mantzaris, G. Papadimitriou, A., \& Antsaklis, A. (2007). Evaluation of abnormal uterine bleeding by transvaginal 3-D hysterosonography and diagnostic hysteroscopy. Eur. J. Gynaecol. Oncol., 28 (1), 39-42.

40. Jansen, F.W., de Kroon, C.D., van Dongen, H., Grooters, C., Louwé, L., \& Trimbos-Kemper, T. (2006). Diagnostic hysteroscopy and saline infusion sonography: prediction of intrauterine polyps and myomas. J. Minim. Invasive Gynecol., 13 (4), 320-324.

41. El-Sherbiny, W., El-Mazny, A., Abou-Salem, N., \& Mostafa, W.S. (2015). The diagnostic accuracy of two- vs threedimensional sonohysterography for evaluation of the uterine cavity in the reproductive age. J. Minim. Invasive Gynecol., 22 (1), 127-131.

42. Abou-Salem, N., Elmazny, A., \& El-Sherbiny, W. (2010). Value of 3-dimensional sonohysterography for detection of intrauterine lesions in women with abnormal uterine bleeding. J. Minim. Invasive Gynecol., 17 (2), 200-204.

43. Preutthipan, S., \& Linasmita, V. (2003). A prospective comparative study between hysterosalpingography and hysteroscopy in the detection of intrauterine pathology in patients with infertility. J. Obstet. Gynaecol. Res., 29 (1), 33-37.

44. Svirsky, R., Smorgick, N., Rozowski, U., Sagiv, R., Feingold, M., Halperin, R., \& Pansky, M. (2008). Can we rely on blind endometrial biopsy for detection of focal intrauterine pathology? Am. J. Obstet. Gynecol., 199 (2), 115.

45. Elias, R.T., Pereira, N., Karipcin, F.S., Rosenwaks, Z., \& Spandorfer, S.D. (2015). Impact of newly diagnosed endometrial polyps during controlled ovarian hyperstimulation on in vitro fertilization outcomes. J. Minim. Invasive Gynecol., 22 (4), 590-594.

46. Bosteels, J., Kasius, J., Weyers, S., Broekmans, F.J., Mol, B.W.J., \& D'Hooghe, T.M. (2015). Hysteroscopy for treating subfertility associated with suspected major uterine cavity abnormalities. Cochrane Database Syst. Rev., 2, CD009461. 
47. Carneiro, M.M. (2014). What is the role of hysteroscopic surgery in the management of female infertility? A review of the literature. Surg. Res. Pract., 2014, 6, ID 105412.

48. Deans, R., \& Abbott, J. (2010). Review of intrauterine adhesions. J. Minim. Invasive Gynecol., 17 (5), 555-569.

49. Taylor, E., \& Gomel, V. (2008). The uterus and fertility. Fertil. Steril., 89 (1), 1-16.

50. Afifi, K., Anand, S., Nallapeta, S., \& Gelbaya, T.A. (2010). Management of endometrial polyps in subfertile women: a systematic review. Eur. J. Obstet. Gynecol. Reprod. Biol., 151 (2), 117-121.

51. Bosteels, J., Kasius, J., Weyers, S., Broekmans, F.J., Mol, B.W.J., \& D'Hooghe, T.M. (2015). Hysteroscopy for treating subfertility associated with suspected major uterine cavity abnormalities. Cochrane Database Syst. Rev., 2, CD009461.

52. Pérez-Medina, T., Bajo-Arenas, J., Salazar, F., Redondo, T., Sanfrutos, L., Alvarez, P., \& Engels, V. (2005). Endometrial polyps and their implication in the pregnancy rates of patients undergoing intrauterine insemination: a prospective, randomized study. Hum. Reprod., 20 (6), 1632-1635.

53. Bosteels, J., Kasius, J., Weyers, S., Broekmans, F.J., Mol, B.W.J., \& D'Hooghe, T.M. (2013). Treating suspected uterine cavity abnormalities by hysteroscopy to improve reproductive outcome in women with unexplained infertility or prior to IUI, IVF, or ICSI. Gynecol. Surg., 10 (3), 165-167.

Отримано 02.09.20 Прийнято до друку 06.10.20 Електронна адреса для листування: nikitina1med@gmail.com 